\title{
Muscle Fiber Type Composition, Fiber Diameter, Capillary Density in Temporalis and Masseter Muscles and Correlation with Bite Force
}

\author{
Tipos de Fibras Musculares, Diámetro de Fibras y Densidad Capilar en los \\ Músculos Masetero y Temporal y su Correlación con la Fuerza de Mordida
}

Thatiana Bastos Guimarães*; Mariana Brandão Ferreira*; Alda Wakamatsu*; Stanley Reis Oliveira*; Antonio Sergio Guimarães**; Iván Suazo Galdames*** \& Suely Nagahashi Marie*

GUIMARÃES, T. B.; FERREIRA, M. B.; WAKAMATSU, A.; OLIVEIRA, S. R.; GUIMARÃES, A. S.; SUAZO, G. I. \& MARIE, S. N. Muscle fiber type composition, fiber diameter, capillary density in temporalis and masseter muscles and correlation with bite force. Int. J. Morphol., 31(2):747-753, 2013.

SUMMARY: The jaw muscles are essential components in the stomatognatic system. Their complex architecture allows them to execute several motor tasks. One of the structural peculiarities is the presence of hybrid and neonatal fibers. We studied the differences of the fiber-type in masseter and temporalis muscles along the first to nineth decades in both genders. Seventy-four (74) samples were analyzed by immunohistochemistry. Slow and fast muscle fibers distribution was similar in both muscles in both genders. Hybrid fiber was observed in all decades, and its frequency decreased significantly $(\mathrm{p}<0.001)$ with aging in masseter. Neonatal myosin expression was observed in all decades, its expression was more frequent in masseter $(\mathrm{p}=0.01)$, and males in temporalis $(\mathrm{p}=0.025)$. Decrease of the cross sectional area of fast and slow fibers, and decrease of capillary density were detected with aging. These morpho-immunohistochemical alterations on masseter and temporalis muscles correlated to the decrease in bite force with aging.

KEY WORDS: Masseter; temporalis; Muscle fiber type; Capillary density; Bite force.

\section{INTRODUCTION}

Successful performance of daily oral activities, such as biting, swallowing, chewing and talking require a synchronized function of jaw muscles. Precise position control of the mandible combined with a change of jaw muscle strength is feasible due to the complex architecture of the involved muscles. The speed of muscle contraction depends on the composition of myosin heavy chain $(\mathrm{MyHC})$ isoform composition (Bottinelli et al., 1996)

Muscle fibers have been classified according to the differences in contraction speed, and propensity to fatigability based on immunohistochemical findings (Hoh, 2002; Sciote et al., 2003). Contraction velocity increases progressively from type I, type IIA, type IIX to type IIB, while fatigability decreases in that order (Bottinelli et al.). The fiber-type composition differs within different muscle groups (jaw-closers vs. jaw-openers), and different regions of the same muscle, and different subjects (Korfage \& Van
Eijden, 2003). It is likely that specific function reflects in specific fiber-type composition (Van Eijden \& Turkawski, 2001).

Jaw-muscles notably present more hybrid fibers, containing more than one MyHC isoform, than limb or trunk muscles. These hybrid fibers have contractile properties that differ from the pure fiber, and present intermmediate characteristics from each of the MyHC isoforms they express (Larsson \& Moss, 1993).Thus, hybrid fiber expressing both MyHC-I and IIA, for instance, will be faster than pure MyHC-I fiber but slower than pure MyHC-IIA fiber.

During muscle maturation, developmental MyHC isoforms (embrionic and neonatal) are replaced by adult slow and fast MyHC isoforms in normal adult limb and trunk muscle fibers (Kirkeby \& Garbarsch, 2001). However, developmental MyHC isoforms persist in some adult cranial

* Department of Neurology, University of São Paulo, Av. Dr Arnaldo 455, Cerqueira César, São Paulo-SP 01246-903, Brazil.

** Departament of Anatomy, Federal University of São Paulo, Brazil.

**** Universidad Autónoma de Chile. 
muscles, including the masseter (Korfage \& Van Eijden, 2000), and they may even increase in relative amount with aging (Kirkeby \& Garbarsch).

There are several differences between jaw muscles and limb and trunk muscles. For example, the jaw muscles contain many hybrid fibers, in contrast to limb and trunk muscles. Many of these fibers co-express MyHC-neonatal (Korfage et al., 2001). Also, there is a difference in the fiber diameter between the two fiber type. Type II fibers are larger than type I fibers in limb and trunk muscles, while in jaw muscles the opposite is observed,.Another difference is the jaw muscle fibers are $50 \%$ smaller than limb and trunk muscle fibers (Korfage et al., 2005).

The bite force, or masticatory function, produced by masticatory muscles influences not only occlusal variations and dental arch forms, but also the mandibular shape and structure (Tsunori et al., 1998). Several previous studies have reported bite force as a clinical indicator of masticatory performance. This parameter is correlated with craniofacial morphology (Tsunori et al.), gender (Tate et al., 1994) age (Klitgaard et al., 1990) temporomandibular disorders (TMD) (Pizolato \& Gaviao, 2007), and also with status, number and tooth mobility (Miyaura et al., 1999).

The aims of the present study were to determine: 1) the fiber-type and fiber cross sectional area distribution in masseter and temporal muscles through the aging process, in both genders, 2) the proportion of hybrid and neonatal fibers, capillary density along the nine decades of life, and 3 ) the correlation of these parameters with the masticatory function, the bite force.

\section{MATHERIAL AND METHOD}

Seventy-four autopsy specimens of masseter and temporalis muscles were obtained from the Pathology Department of School of Medicine of University of São Paulo, according to the rules of the necropsy service, within 8 to 18 hour post mortem interval, of both sexes, and from subjects of first to nineth decade of life. It included at least two samples per decade per gender (Table I). For statistical analysis, the samples were grouped into three subgroups: young ( 0 to 25 years of age), adult (26 to 59 years of age) and old (60 and above years of age).

The design of this study was reviewed and approved by the local ethical committee.

Fragments of $2 \times 2 \times 1 \mathrm{~cm}$ were collected from deep and posterior portions of masseters by extraoral access, and from medium and superficial temporalis by superior access.

Fifty-two (52) subjects (26 females, 26 males) age and sex matched controls ( 8 to 75 years), without temporomandibular disorders were included for the measurement of bite force.

Immunohistochemistry. The muscle specimens were mounted for transverse sectioning and snap frozen in liquid nitrogen. Serial $6 \mu \mathrm{m}$ thick cross-sections were prepared in a cryostat microtome (MICROM HM 505E) at $-25^{\circ} \mathrm{C}$, and were kept stored in $-80^{\circ} \mathrm{C}$ until used for histological, and immunohistochemical stainings.

Fiber-type classification was based on the staining pattern for immunohistochemical myosin heavy chain slow antibody (clone WB-MHCs, Novocastra, dilution 1:80), and myosin heavy chain fast antibody (clone WB-MHCf Novocastra, dilution 1:40). The presence of neonatal fiber was determined by myosin heavy chain neonatal antibody (cloneWB-MHCn, Novocastra, dilution 1:40), and the capillary density with ulex europaeus aglutinin I (clone B1065 Vector, dilution 1:800) staining.

The cross-sections were photographed in 3 to 4 areas using the Nikon-Eclipse E800. Classification of fiber type was performed in at least 500 muscle fibers from each muscle sample at 200 times magnification.

The histograms were obtained from a computer program (CELL) developed specifically for cellular morphometric studies for the myopathy laboratory of the Department of Neurology at the University of São Paulo.

Isolation of fixed single muscle fibers. The isolation of fixed single muscle was prepared from muscle biopsies obtained from one specimen from a 39-year-old. The biopsy specimen was removed and pinned to sylgard-coated dishes for fixation with $2 \%$ paraphormaldeyde in $0.1 \mathrm{M}$ phosphate buffer for $30 \mathrm{~min}$, followed by PBS rinses and fixation in cold methanol $\left(-20^{\circ} \mathrm{C}\right)$ for $6 \mathrm{~min}$. Samples were stored in $50 \%$ glycerol in $\mathrm{PBS}$ at $-20^{\circ} \mathrm{C}$. Before use, each sample was transferred first to $25 \%$ glycerol/PBS, then to $12 \%$ glycerol/ PBS, and finally to PBS/ $0.04 \%$ saponin. Single fiber was obtained by manual teasing. The isolated fibers were placed in blocking buffer (1\% BSA, $5 \%$ goat serum and $0.2 \%$ triton in PBS) for $1 \mathrm{~h}$. The permeabilized fibers were then incubated with primary antibody overnight at $4^{\circ} \mathrm{C}$, washed in PBS, incubated with second antibody for $2 \mathrm{~h}$ at room temperature, washed and mounted in Vectashield (Vector Laboratories, Burlingame, CA) on glass slides for analysis by confocal microscopy. 
Bite Force. A gnathodynamometer (Kratos Equipment Industriais, Ltd., Model IDDK) was used for measurement of maximum isometric bite force. Measurements were taken with the patient comfortably seated in a dental chair. The stainless steel cylinder was wrapped by a plastic shield, and changed for each patient. The maximum isometric bite force was quantified (in kgf) in the molar region bilaterally at points where the subject felt safer to develop the maximum strength. Measurement was accomplished three times on each side, with a 30-s interval between measurements to avoid muscular fatigue. The average value was considered for analysis.

Statistical analysis. Comparisons between two groups was used the $t$ student test or the Mann-Whitney, and for three groups used the ANOVA or the Kruskal-Wallis test. The significance level was set at $\mathrm{p}<0.05$.

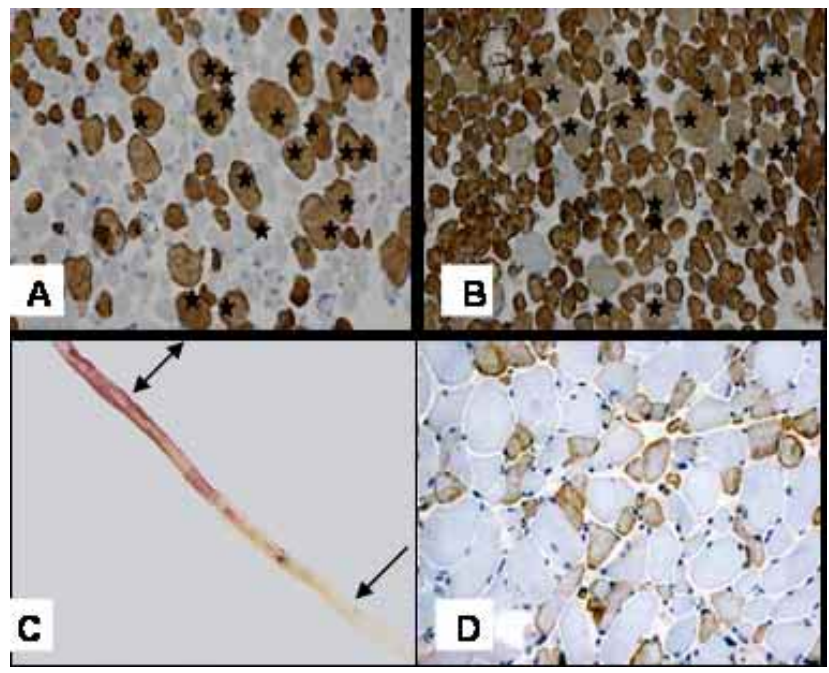

Fig. 1. Imunohistochemical preparations on sequential sections of masseter muscle of $3^{\text {rd }}$ decade male with the antibodies against MyHC slow (A) and fast (B), showing the double staining (black star). C: single muscle fiber manually teased from the masseter muscle of 4th decade male prepared with antibody agaist MyHC slow demonstrating the presence of a portion of the fiber stained (double arrow head) and other without reaction (arrow), proving the presence of hybrid fiber. D: Temporali muscle from 2nd decade male prepared with antibody againt MyHCneonatal showing the presence of neonatal fibers stained (in brown)

\section{RESULTS}

Fiber-type Distribution. Slow and fast muscle fiber distributions were similar in masseter and temporalis muscles in both sexes along the nine decades of age. However, when the fiber-type distribution was analyzed in the three subgroups, fast muscle fibers significantly predominated
( $\mathrm{p}=0.023)$ in masseters in the old group. The cross sectional area of fast muscle fibers was smaller than the slow fibers along the nine studied decades. Moreover, the cross sectional areas decreased with aging in both type of fibers. Furthermore, this decrease was more evident in fast fibers (Fig. 2A, Table I).

Hybrid fibers were observed throughout the first to ninth decades of age in 4 samples in both masseter and temporalis in each decade. Interestingly, its frequency decreased in both muscles with aging, being significant in masseter ( $<<0,001)$ (Fig. 2B, Table I).

The striking observation was the presence of numerous muscle fibers expressing neonatal myosin all along the nine decades. Only 9 (12\%) of 74 samples presented no neonatal fibers in analyzed muscle fragment. Neonatal fibers were more frequent in the masseter $(\mathrm{p}=0.01)$, and predominated in males in the temporalis $(\mathrm{p}=0.025)$ (Table I).

Additionally, capillary density drop out was detected in both muscles, with more marked decrease with aging in masseter (Fig. 2C, Table I).

The bite force decreased with age (Fig. 1D, Table I), interestingly in parallel to the decrease of the cross sectional area, mainly in fast fibers, the decrease in the number of hybrid fibers, and also the decrease of capillary density.

The mean of capillary density, fast, slow and neonatal myosin expression, hybrid fiber and bite force. $\mathrm{N}=$ number of samples with the presence of neonatal fiber (Table I).

\section{DISCUSSION}

The major contribution of the present study is the systematic morphometric analysis of two jaw muscles, masseter and temporalis, along nine decades of age, addressing the characteristics of masticatory muscles which differ from limb muscles.

To this end, fast and slow-twitch fiber distribution, cross sectional area of both fiber-types, presence of hybrid and neonatal fibers, and capillary density were analyzed in 74 muscle samples. These quantitative results were compared to a masticatory function, the bite force.

In the present study, the slow and fast muscle fiber distributions were similar in both masseter and temporalis muscles in both sexes along the nine decades of age, in the 
GUIMARÃES, T. B.; FERREIRA, M. B.; WAKAMATSU, A.; OLIVEIRA, S. R.; GUIMARÃES, A. S.; SUAZO, G. I. \& MARIE, S. N. Muscle fiber type composition, fiber diameter, capillary density in temporalis and masseter muscles and correlation with bite force. Int. J. Morphol., 31(2):747-753, 2013.

present study, corroborating previous report by others (Lexell, 1995). Several other studies including less number of cases, and also variable age range demonstrated differential distribution of fiber types in masticatory muscles (Shaughnessy et al., 1989; Monemi et al., 1998; Stal et al., 1994; Raoul et al., 2011). The great individual variability were due to differences in chewing patterns, which were dependent on type of food, artificial dentures, craniofacial morphology, and hormones, among other factors that may explain these discrepancies (Korfage et al., 2005).

This is the first analysis of cross sectional area of fiber types with the process of aging. Previous studies have already shown that fast fibers present smaller cross- sectional area than slow fibers in masticatory muscles (Vignon et al.; Korfage \& Van Eijden, 2000). We found that there is a linear decrease of cross sectional area in both masseter and temporalis, and additionally fast fiber diameter decreases more markedly than slow fiber diameter with aging.

Hybrid fibers were detected in both masseter and temporalis muscles, as reported previously (Ringqvist; Monemi et al., 1998). However, a temporal observation of its presence along the process of aging was missing. We found a linear decrease of hybrid fibers in masseter and temporalis along the nine decades of age.

Table I. Show the mean of capillary density, fast, slow and neonatal myosin expression, hybrid fiber and bite force. $\mathrm{N}=$ number of samples with the presence of neonatal fiber.

\begin{tabular}{|c|c|c|c|c|c|c|c|c|c|c|}
\hline \multirow{3}{*}{$\begin{array}{c}\mathbf{N} \\
\text { Total }\end{array}$} & \multirow{3}{*}{\multicolumn{2}{|c|}{$\begin{array}{l}\text { Capilarie } \\
\text { edensity } \\
(n=60)\end{array}$}} & \multirow{2}{*}{\multicolumn{2}{|c|}{ Fast myosin $(n=74)$}} & \multirow{2}{*}{\multicolumn{2}{|c|}{ Slow myosin $(n=74)$}} & \multicolumn{2}{|c|}{ Neonatal } & \multirow{3}{*}{$\begin{array}{l}\text { Hibrid } \\
\text { Fiber } \\
(n=36)\end{array}$} & \multirow{3}{*}{$\begin{array}{c}\text { Bite force } \\
\begin{array}{c}\text { Kgf } \\
(n=54) .\end{array}\end{array}$} \\
\hline & & & & & & & \multicolumn{2}{|c|}{ myosin $\quad(n=63)$} & & \\
\hline & & & $\%$ & Mean $\varnothing$ & $\%$ & Mean $\varnothing$ & $\mathbf{N}$ & Mean & & \\
\hline 4 & $\mathrm{M}$ & $214.0 \pm 30.1$ & $71.9 \pm 20.3$ & $12.2 \pm 1.2$ & $98.3 \pm 15.8$ & $15.1 \pm 3.7$ & 4 & $63.0 \pm 31.7$ & $68.0 \pm 5.7$ & \\
\hline 4 & $\mathrm{~T}$ & $238.0 \pm 27.7$ & $65.9 \pm 13.6$ & $12.7 \pm 3.0$ & $78.3 \pm 22.2$ & $17.5 \pm 2.5$ & 4 & $57.3 \pm 30.2$ & $86.0 \pm 4.2$ & \\
\hline 3 & $M$ & $252.0 \pm 36.7$ & $76.7 \pm 17.9$ & $33.7 \pm 6.8$ & $71.4 \pm 5.7$ & $41.5 \pm 5.6$ & 3 & $28.1 \pm 31.3$ & $54.0 \pm 4.2$ & \\
\hline 3 & $\mathrm{~T}$ & $122.0 \pm 20.5$ & $44.0 \pm 20.0$ & $26.8 \pm 12.8$ & $57.2 \pm 8.4$ & $33.5 \pm 10.1$ & 3 & $18.6 \pm 15.1$ & $25.0 \pm 19.1$ & $35.0 \pm 6.8$ \\
\hline 3 & M & $165.0 \pm 11.2$ & $75.9 \pm 10.3$ & $24.6 \pm 16.7$ & $89.3 \pm 4.8$ & $32.2 \pm 9.71$ & 2 & $62.0 \pm 32.4$ & $58.0 \pm 6.4$ & \\
\hline 3 & $\mathrm{~T}$ & $139.0 \pm 23.5$ & $89.2 \pm 24.9$ & $45.8 \pm 5.0$ & $76.1 \pm 11.1$ & $48.3 \pm 5.8$ & 3 & $22.6 \pm 33.0$ & $45.0 \pm 10.3$ & $50.5 \pm 18.6$ \\
\hline 4 & M & $175.0 \pm 68.3$ & $53.8 \pm 22.5$ & $24.9 \pm 9.4$ & $60.5 \pm 5.4$ & $42.0 \pm 6.4$ & 3 & $35.5 \pm 11.6$ & $39.0 \pm 5.3$ & \\
\hline 4 & $\mathrm{~T}$ & $149.0 \pm 33.0$ & $91.3 \pm 27.9$ & $28.3 \pm 5.6$ & $48.3 \pm 13.9$ & $57.4 \pm 16.3$ & 4 & $31.8 \pm 18.7$ & $43.0 \pm 23.3$ & $45.0 \pm 17.6$ \\
\hline 5 & $M$ & $134.5 \pm 36.5$ & $24.4 \pm 21.2$ & $25.9 \pm 13.3$ & $64.9 \pm 15.9$ & $40.4 \pm 10.4$ & 5 & $57.2 \pm 35.6$ & $31.0 \pm 2.8$ & \\
\hline 5 & $\mathrm{~T}$ & $42.0 \pm 36.5$ & $92.5 \pm 20.7$ & $30.1 \pm 14.8$ & $70.4 \pm 16.8$ & $36.7 \pm 7.5$ & 4 & $27.6 \pm 22.7$ & $39.0 \pm 13.4$ & \\
\hline 5 & $M$ & $137.0 \pm 20.6$ & $97.8 \pm 10.6$ & $28.2 \pm 12.9$ & $63.5 \pm 14.4$ & $12.0 \pm 10.5$ & 5 & $34.2 \pm 38.3$ & $28.0 \pm 2.8$ & \\
\hline 5 & $\mathrm{~T}$ & $135.0 \pm 41.4$ & $54.5 \pm 13.5$ & $26.4 \pm 10.2$ & $70.9 \pm 13.5$ & $40.1 \pm 8.34$ & 5 & $21.3 \pm 1.2$ & $23.0 \pm 0.7$ & \\
\hline 4 & $M$ & $126.0 \pm 29.9$ & $76.1 \pm 11.6$ & $20.1 \pm 7.64$ & $33.1 \pm 19.1$ & $33.1 \pm 6.1$ & 3 & $56.6 \pm 28.7$ & $33.0 \pm 12.0$ & \\
\hline 4 & $\mathrm{~T}$ & $168.0 \pm 58.2$ & $67.9 \pm 20.9$ & $18.6 \pm 6.4$ & $66.0 \pm 15.7$ & $33.2 \pm 8.8$ & 3 & $36.4 \pm 28.2$ & $19.0 \pm 4.2$ & \\
\hline 5 & $M$ & $101.0 \pm 19.7$ & $58.1 \pm 17.3$ & $20.5 \pm 10.6$ & $58.1 \pm 11.4$ & $33.7 \pm 7.1$ & 4 & $23.0 \pm 10.3$ & $23.0 \pm 2.8$ & $16.1 \pm 8.6$ \\
\hline 5 & $\mathrm{~T}$ & $104.0 \pm 75.7$ & $73.4 \pm 17.6$ & $27.0 \pm 10.9$ & $68.6 \pm 12.4$ & $37.2 \pm 3.42$ & 3 & $8.6 \pm 10.35$ & $24.0 \pm 4.2$ & \\
\hline 4 & $M$ & $134.5 \pm 28.9$ & $72.5 \pm 22.8$ & $14.8 \pm 4.4$ & $85.7 \pm 28.5$ & $31.6 \pm 10.4$ & 3 & $62.8 \pm 20.0$ & $22.0 \pm 8.5$ & \\
\hline 4 & $\mathrm{~T}$ & $100.0 \pm 64.0$ & $66.4 \pm 15.9$ & $16.1 \pm 3.4$ & $69.9 \pm 8.5$ & $32.7 \pm 6.5$ & 4 & $28.5 \pm 24.0$ & $28.0 \pm 14.8$ & $21.1 \pm 12.1$ \\
\hline
\end{tabular}




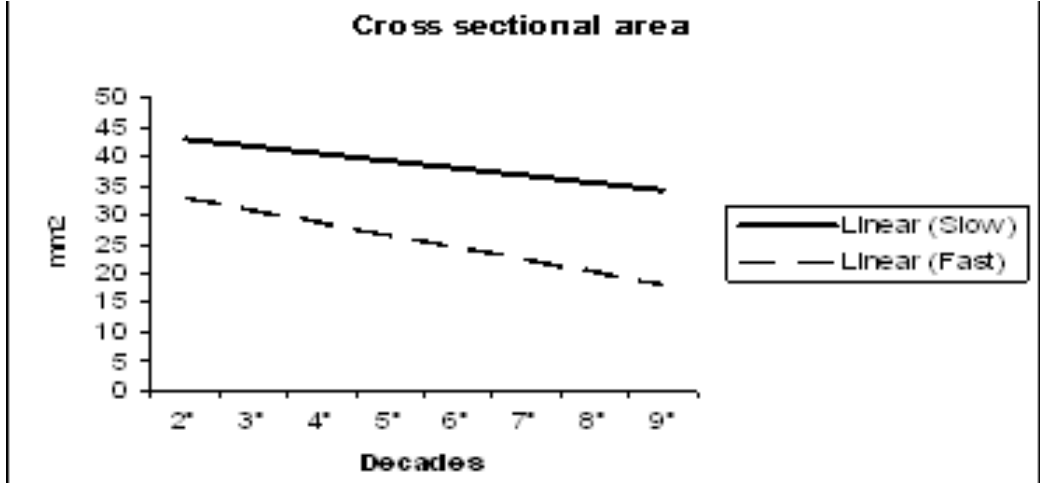

Hybrid Fiber
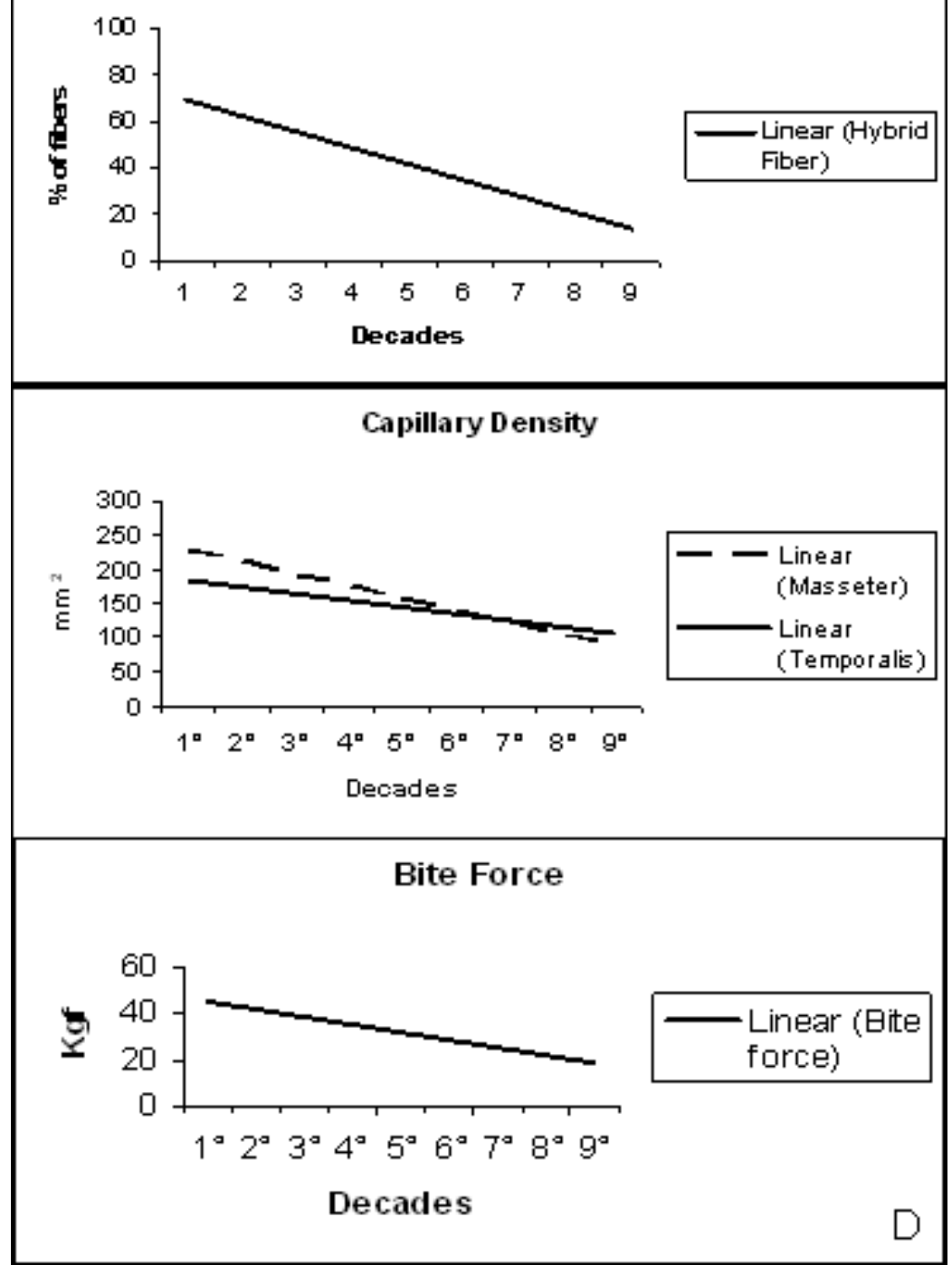

Fig. 2. Graphics of cross section area (A), hybrid fiber (B), capillary density (C) and bite force (D) showing the linear and tendency of the alterations along the nine decades of age.
A possible explanation for this finding may be attributed to the difference of innervation between limb and trunk muscles, namely brachial and spinal. Other reason for the presence of hybrid fiber may be due to specific functional demands of the masticatory muscles. Hybrid fibers allow widening the spectrum of motor tasks, as their contractile properties lie between those of the pure fibers. Hybrid fibers also occur during the regeneration process. Sarcolema of normal muscle fiber may occasionally rupture by stretch and/or stimulation (Petrof et al., 1993) or ischemia, toxicity to medication, reloading or reperfusion trauma may stimulate satellite cells to repair the damage. During this regenerative process, fibers transiently express MyHC-neonatal and MyHC-I (Korfage \& Van Eijden , 1999).

Interestingly, muscle fibers expressing neonatal myosin were observed along the nine decades of age. This myosin isoform is expected to be present only in developing muscle fibers, mainly fast myoblast, and not in mature fibers (Sarnat, 1991). However, its presence has been reported in different masticatory muscles, including masseter and temporalis in different ages, and quantities (Monemi et al., 1999). To address the finding of continuous presence of neonatal fibers up to senescence, we tested the hypothesis whether a vascular change with aging may trigger a regenerative process with an increase of neonatal fibers. A previous study reported a high capillary density in masseter compared to limb muscle (Stal et al., 1996). Therefore, we analyzed the capillary density in masseter and temporalis, and observed its linear decrease with aging, which was more striking in masseter.

Thus, the drop out of capillaries in both muscles may lead to a hypoxic condition which may trigger the expression of neonatal myosin. This hypoxemia may also explain the atrophy observed in both fiber types, mainly of fast fibers.

In an attempt to correlate the morphological findings to a functional 
behavior, we have measured the bite force in age and gender matched controls. Previous study has reported that bite force increases up to the age of 25 in females, and decreases significantly afterwards, while in males the decrease occurr after 45 year-old (Dakke et al., 1990). We have demonstrated a linear decrease of bite force in both genders along the nine decades of age. This decrease in masticatory function might be associated with the morphological findings observed in the present study, specifically the decrease of muscle fiber diameter, mainly in the fast fibers, drop-out of capillary density, and decrease of hybrid fibers along the process of aging.

In conclusion, the jaw muscles proved to be highly unusual compared to limb and trunk muscles. Masseter and temporalis muscles contain many hybrid fibers, which numbers decrease with aging, and numerous neonatal fibers in the majority of samples over nine decades of age. We also observed a decreased in the capillary density and of the cross sectional area; together, all findings may be related to the decrease in bite force with aging.

GUIMARÃES, T. B.; FERREIRA, M. B.; WAKAMATSU, A.; OLIVEIRA, S. R.; GUIMARÃES, A. S.; SUAZO, G. I. \& MARIE, S. N. Tipos de fibras musculares, diámetro de fibras y densidad capilar en los músculos masetero y temporal y su correlación con la fuerza de mordida. Int. J. Morphol., 31(2):747-753, 2013.

RESUMEN: Los músculos cráneomandibulares son componentes esenciales en el sistema estomatognático. Su arquitectura compleja les permite ejecutar variadas tareas motoras. Una de sus características estructurales es la presencia de fibras musculares híbridas y neonatales. Se estudiaron las diferencias del tipo de fibra en los músculos masetero y temporal en la primera a novena décadas dela vida en ambos sexos. Setenta y cuatro (74) muestras se analizaron por inmunohistoquímica. La distribución de lãs fibras musculares lentas y rápidas fue similar en ambos músculos en ambos sexos. Fibras musculares híbridas fueron observadas en todas las décadas, pero su frecuencia disminuyó significativamente $(\mathrm{p}<0,001)$ con el envejecimiento en el masétero. La expresión de miosina neonatal se observo em todas los grupos analizados, aunque su expresión era más frecuente en los músculos maseteros $(\mathrm{p}=0,01)$ y en varones en el temporal $(\mathrm{p}=0,025)$. Se observo una disminución del área de la sección transversal de las fibras rápidas y lentas, y disminución de la densidad capilar al aumentar La edad. Estas alteraciones morfológicas en los músculos masetero y temporal se correlacionan con la disminución de la fuerza asociada al envejecimiento.

PALABRAS CLAVE: Masetero; Temporal; Tipos de fibras musculares; Densidad capilar; Fuerza de mordida.

\section{REFERENCES}

Bakke, M.; Holm, B.; Jensen, B. L.; Michler, L. \& Möller, E. Unilateral, isometric bite force in 8-68-year-old women and men related to occlusal factors. Scand. J. Dent. Res., 98(2):149-58, 1990.

Bottinelli, R.; Canepari, M.; Pellegrino, M. A. \& Reggiani, C. Force-velocity properties of human skeletal muscle fibres: myosin heavy chain isoform and temperature dependence. J. Physiol., 495(Pt 2):573-86, 1996.

Hoh, J. F. 'Superfast' or masticatory myosin and the evolution of jaw-closing muscles of vertebrates. J. Exp. Biol., 205:220310, 2002.

Kirkeby, S. \& Garbarsch, C. Histochemical studies of the masseter, the temporal and small zygomaticomandibular, and the temporomandibular masticatory muscles from aged male and female humans. Fiber types and myosin isoforms. Cranio, 19(3):174-82, 2001 .

Klitgaard, H.; Zhou, M.; Schiaffino, S.; Betto, R.; Salviati, G. \& Saltin, G. Ageing alters the myosin heavy chain composition of single fibres from human skeletal muscle. Acta Physiol. Scand., 140(1):55-62, 1990.
Korfage, J. A. \& Van Eijden, T. M. Myosin heavy chain composition in human masticatory muscles by immunohistochemistry and gel electrophoresis. J. Histochem Cytochem., 51(1):113-19, 2003.

Korfage, J. A. \& Van Eijden, T. M. Regional differences in fibre type composition in the human temporalis muscle. J. Anat., 194(Pt 3):355-62, 1999.

Korfage, J. A.; Koolstra, J. H.; Langenbach, G. E. \& van Eijden, T. M. Fiber-type composition of the human jaw muscles--(part 2) role of hybrid fibers and factors responsible for inter-individual variation. J. Dent. Res., 84(9):784-93, 2005.

Korfage, J. A.; Schueler, Y. T.; Brugman, P. \& Van Eijden, T. M. Differences in myosin heavy-chain composition between human jaw-closing muscles and supra- and infrahyoid muscles. Arch. Oral Biol., 46(9):821-7, 2001.

Larsson, L. \& Moss, R. L. Maximum velocity of shortening in relation to myosin isoform composition in single fibres from human skeletal muscles. J. Physiol., 472:595-614, 1993.

Lexell, J. Human aging, muscle mass, and fiber type composition. J. Gerontol., 50:11-6, 1995. 
GUIMARÃES, T. B.; FERREIRA, M. B.; WAKAMATSU, A.; OLIVEIRA, S. R.; GUIMARÃES, A. S.; SUAZO, G. I. \& MARIE, S. N. Muscle fiber type composition, fiber diameter, capillary density in temporalis and masseter muscles and correlation with bite force. Int. J. Morphol., 31(2):747-753, 2013.

Miyaura, K.; Matsuka, Y.; Morita, M.; Yamashita, A. \& Watanabe, T. Comparison of biting forces in different age and sex groups: a study of biting efficiency with mobile and non-mobile teeth. J. Oral Rehabil., 26(3):223-7, 1999.

Monemi, M.; Eriksson, P. O., Eriksson, A. \& Thornell, L. E. Adverse changes in fibre type composition of the human masseter versus biceps brachii muscle during aging. J. Neurol. Sci., 154(1):35-48, 1998.

Monemi, M.; Eriksson, P. O.; Kadi, F.; Butler-Browne, G. S. \& Thornell, L. E. Opposite changes in myosin heavy chain composition of human masseter and biceps brachii muscles during aging. J. Muscle Res. Cell Motil., 20(4):351-61, 1999.

Petrof, B. J.; Stedman, H. H.; Shrager, J. B.; Eby, J.; Sweenwy, H. L. \& Kelly, A. M. Adaptations in myosin heavy chain expression and contractile function in dystrophic mouse diaphragm. Am. J. Physiol., 265(3 Pt 1):C834-41, 1993.

Pizolato, R. A.; Gaviao, M. B.; Berretin-Felix, G.; Sampaio, A. C. $\&$ Trindade Junior, A. S. Maximal bite force in young adults with temporomandibular disorders and bruxism. Braz. Oral Res., 21(3):278-83, 2007.

Raoul, G.; Rowlerson, A.; Sciote, J.; Codaccioni, E.; Stevens, L; Maurage, C. A.; Duhamel, A. \& Ferri, J. Masseter myosin heavy chain composition varies with mandibular asymmetry. J. Craniofac. Surg., 22(3):1093-8, 2011.

Sarnat, H. B. Vimentin/desmin immunoreactivity of myofibres in developmental myopathies. Acta Paediatr. Jpn., 33(2):238-46, 1991.

Sciote, J. J.; Horton, M. J.; Rowlerson, A. M. \& Link, J. Specialized cranial muscles: how different are they from limb and abdominal muscles?. Cells Tissues Organs, 174(1-2):73-86, 2003.

Shaughnessy, T.; Fields, H. \& Westbury, J. Association between craniofacial morphology and fiber-type distributions in human masseter and medial pterygoid muscles. Int. J. Adult Orthodon. Orthognath. Surg., 4(3):145-55, 1989.

Stal, P.; Eriksson, P. O. \& Thornell, L. E. Differences in capillary supply between human oro-facial, masticatory and limb muscles. J. Muscle Res. Cell Motil., 17(2):183-97, 1996.

Tate, G. S.; Throckmorton, G. S.; Ellis, E. 3rd. \& Sinn, D.P. Masticatory performance, muscle activity, and occlusal force in preorthognathic surgery patients. J. Oral Maxillofac. Surg., 52(2):476-81, 1994.

Tsunori, M.; Mashita, M. \& Kasai, K. Relationship between facial types and tooth and bone characteristics of the mandible obtained by CT scanning. Angle Orthod., 68(6):557-62, 1998.

van Eijden, T. M. \& Turkawski, S. J. Morphology and physiology of masticatory muscle motor units. Crit. Rev. Oral Biol. Med., 12(1):76-91, 2001.

\section{Correspondence to: \\ Prof. Dr. Iván Suazo Galdames \\ Universidad Autónoma de Chile \\ CHILE}

Email: ivan.suazo@uautonoma.cl

Received: 06-02-2013

Accepted: 21-03-2013 